\title{
Soil Quality Indicators in Al-Qalyubia Governorate as Affected by Long-term Wastewater Irrigation
}

\author{
Ahmed S. Abuzaid \\ Soil and Water Department, Faculty of Agriculture, Benha University, Egypt
}

\begin{abstract}
THE SUSTAINABLE irrigated agriculture in Egypt is threatened by water stress that made the reuse of wastewater an alternative option not only in the sandy desert soils but also in the alluvial soils. To assess the impacts of long-term wastewater irrigation on soil quality, soils have been irrigated with the effluents of Al-Qalyubia drain beside adjacent Nile fresh waterirrigated soils (reference), sampled and analyzed. The wastewater irrigation improved fertility status, causing significant increases $(\mathrm{P}<0.05)$ in total $\mathrm{N}$ and AB-DTPA extractable $\mathrm{P}, \mathrm{Fe}$ and Mn compared to the reference soils. However, there was a significant $(\mathrm{P}<0.05)$ build-up in soil salinity and total heavy metals; $\mathrm{Cd}, \mathrm{Cr}, \mathrm{Co}, \mathrm{Cu}, \mathrm{Ni}, \mathrm{Pb}$ and $\mathrm{Zn}$ in the wastewater-irrigated soils over the reference soils. The Dutch model indicated that the Nile fresh water remained safe for agricultural production, while the wastewater-irrigated soils could be used under certain precautions. Focal measures are recommended to alleviate heavy metal contaminants to avoid potential environmental risks including mixing the wastewater with the fresh water before use and implementation of proper on-farm treatments.
\end{abstract}

Keywords: Soil quality, Wastewater irrigation, Al-Qalyubia Governorate

\begin{abstract}
Introduction
Egypt is water stressed due to aridity, limited natural water resources and increased demand for industrial, domestic and agricultural sectors (Abdel Meguid, 2017). The Nile River is the major source for water supply in Egypt. It provides 55.5 billion $\mathrm{m}^{3}$ year $^{-1}$ that accounts for more than $90 \%$ of the water budget, while the remaining $10 \%$ comes from renewable and fossil groundwater beside a few showers of rainfall (ICARDA, 2011). The agriculture sector is the main consumer of fresh water, which consumes $80-85 \%$ of water resources (Mahmoud and El-Bably, 2017). The present water supplies are not adequate to maintain sustainable irrigated agricultural, and hence unconventional wastewater resources provide an alternative supply to fulfill the increased demand (Soliman, 2015). Using such waters helps to diminish the gap between supply and demand, prevent contamination of freshwater supplies and provide a solution to water shortage and climate change (Loutfy, 2011 and Ali et al., 2013). Soil quality indicators are a combination of measurable physical,chemical and biological soil properties used to monitor changes in the soil capacity to function within natural or managed ecosystem boundaries (Yao et al., 2013). The physical indicators are related to the retention and
\end{abstract}

transport of water, air, and nutrients. Examples include texture, bulk density, and water holding capacity. The chemical indicators determine soilplant relations, including $\mathrm{pH}, \mathrm{EC}$, organic carbon, plant nutrients and potential contaminants. The biological indicators include microbial biomass $\mathrm{C}$ and $\mathrm{N}$, potentially mineralized $\mathrm{N}$ and soil respiration (Wienhold et al., 2004). These indicators are affected by agricultural management practices, as the latter cause modifications in soil properties as well as in soil biotic community (Marzaioli et al., 2010).

Attention has been paid to wastewater irrigation which has a notable effect on soil quality under different conditions (Masto et al., 2009 and Rezapour \& Samadi, 2011). With the beginning of adopting wastewater irrigation in Nile Delta region since the mid-nineties of the last century (Rashed et al., 1995), positive and negative effects on soil quality have been reported. Benefits were enriching the soil with organic carbon, macro, and micro nutrients, but harmful effects were involved, particularly toxic heavy metal accumulation (Galal, 2015 and Mahmoud $\&$ Ghoneim, 2016). Thus, the effective and safe use of wastewater for irrigation requires careful applications of wastewater (Zidan and Dawoud, 
2013). In addition, periodic monitoring and evaluation for soil quality should be conducted (Yadav et al., 2015). In this concern, the current study aimed at monitoring the changes of the physicochemical properties and heavy metals accumulation in alluvial soils in Al-Qalyubia Governorate which have been subjected to longterm wastewater irrigation in comparison to soils irrigated with the Nile fresh water.

\section{Materials and Methods}

The area of study

The studied area is located at Tokh District, Al-Qalyubia Governorate between $30^{\circ} 23^{\prime}$ ' $40.918^{\prime \prime}$ to $30^{\circ} 18^{\prime} 42.242^{\prime \prime} \mathrm{N}$ and $31^{\circ} 14^{\prime} 21.667^{\prime \prime}$ to $31^{\circ} 14^{\prime} 49.795^{\prime \prime} \mathrm{E}$ (Fig. 1), covering agricultural fields along the banks of Al-Qalyubia drain. The drain conveys treated and untreated mixes of agricultural, industrial and domestic effluents to Bahr El-Baqar drain that extends northward to Lake Manzala. Farmers have applied these effluents directly to the soil seasonally during water shortage, especially in the summer season for more than 25 years in a furrow application. The area is characterized by hot arid summer and mild rainy winter. The mean annual temperature is $20.3{ }^{\circ} \mathrm{C}$ and the highest temperature $\left(36.7^{\circ} \mathrm{C}\right)$ occurs in July, while the lowest $\left(6.4^{\circ} \mathrm{C}\right)$ occurs in January. The annual precipitation is $65.6 \mathrm{~mm}$.
The soils are classified according to Soil Survey Staff (2014) as Typic Haplotorrerts with Thermic temperature and Torric moisture regimes.

\section{Samples collections}

Nine soil samples were collected from the wastewater-irrigated farms (S1:S9) along the banks of the drain covering a distance of 10.30 $\mathrm{km}$ during 2016 summer season. A nearby area irrigated with the Nile fresh water through KamBattin Canal (R1:R9) was selected for nine reference soil samples (Fig. 2). At each crop farm, five surface soil samples $(0-30 \mathrm{~cm})$ were collected using a stainless-steel auger and well-mixed in a preventative composite sample. Along with soil samples, three water samples were collected from the drain and another three from the fresh water canal using plastic bottles.

\section{Soil and water analysis}

Soil samples were air-dried, crushed and passed through a 2-mm mesh. Soil chemical properties; $\mathrm{pH}, \mathrm{EC}$, organic matter $(\mathrm{OM})$, total $\mathrm{N}$ were determined following the standard methods of Sparks et al. (1996). Available P, $\mathrm{K}$, and micronutrients were extracted using the AB-DTPA (ammonium bicarbonate-diethylene triaminepentaacetic acid) solution at $\mathrm{pH} \quad 7.6$ (Soltanpour and Schwab, 1977).

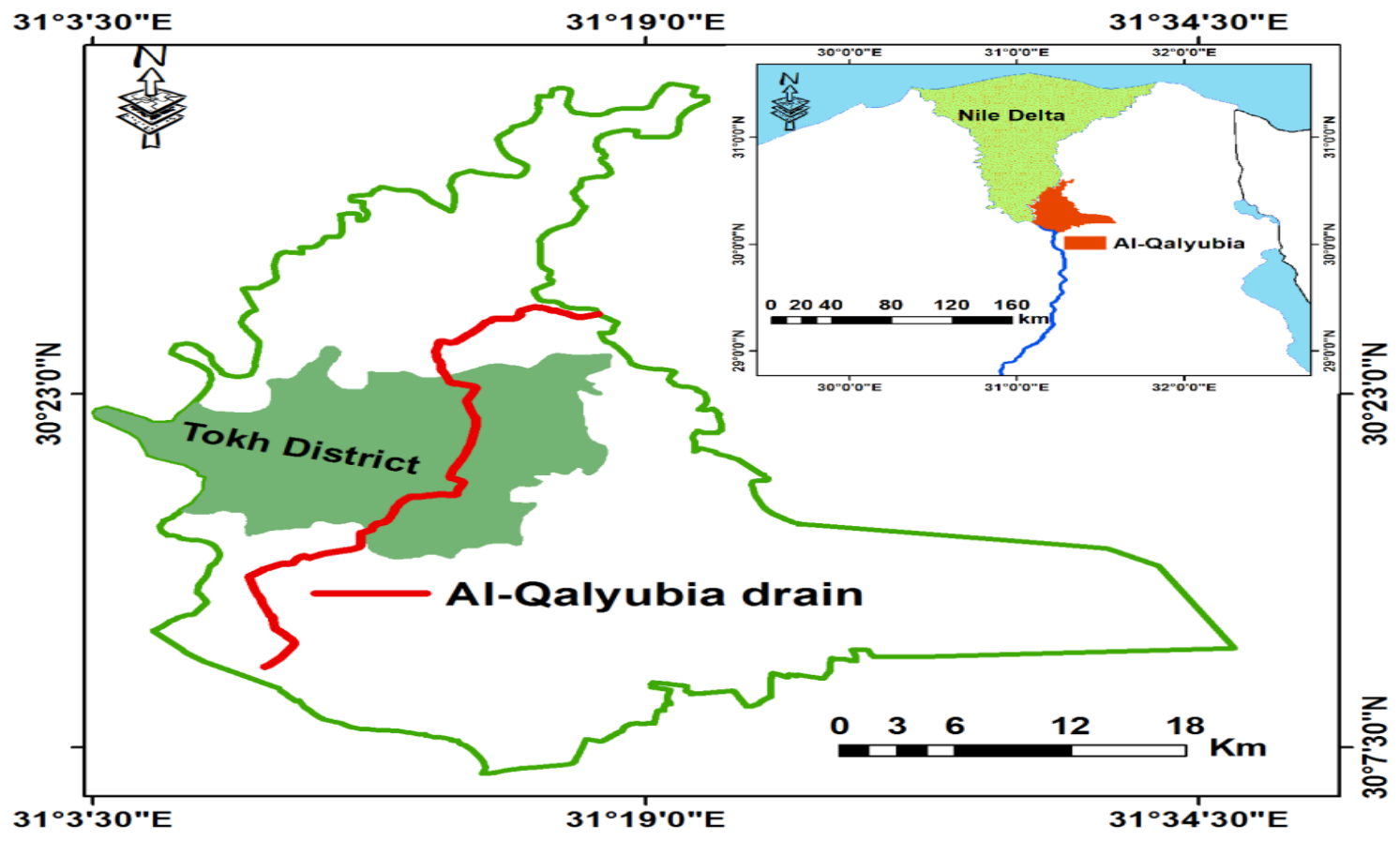

Fig. 1. Location map of the studied area 
Soil physical properties; particle size distribution, water holding capacity and bulk density were determined according to Klute (1986). The total forms of heavy metals were extracted using the Aqua regia digestion (PeñaIcart et al., 2011) and the metals were measured in the filtrate using ICP-OES. Water analyses were performed according to APHA (2005). Water $\mathrm{pH}$ and $\mathrm{EC}$ were measured in-situ using $\mathrm{pH}$ and $\mathrm{EC}$ meters, respectively while other constituents were determined in the lab.

\section{Heavy metals status in the soil}

The Dutch model (from Dutch standard-1988, quoted by Lacatusu, 1998) was used for interpreting the heavy metal contamination/ pollution $(\mathrm{C} / \mathrm{P})$ in soils. This system takes into account the clay and organic matter to estimate the limits between classes since these two macro-constituents directly affect other soil physicochemical properties, determining the maximum soil capacity for metals (Lacatusu, 1998). The system uses three standard levels; the natural background level (A), which is calculated from the clay and organic matter; the maximum allowable limits for agricultural purposes (B) and the levels calling immediate soil decontamination measures (C). The $\mathrm{C} / \mathrm{P}$ index was calculated as the ratio between the total metal content in soil and the reference level. Soil contamination occurs at $\mathrm{C} / \mathrm{P}$ value lower than 1.0 and involves five intervals; very slight $(<0.1)$, slight $(0.1-0.25)$, moderate $(0.26-0.50)$, severe $(0.51-0.75)$ and very severe (0.76-1.00), On the other hand, the higher values are distinguishing soil pollution which house five intervals; slight (1.1-2.0), moderate (2.1-4.0), severe $(4.1-8.0)$, very severe $(8.1-16.0)$ and excessive $(>16.0)$. The multiple pollution index (Nunes et al., 2003), the summation of the single pollution indexes of metals, was also calculated to estimate the overall pollution.

\section{Statistical analysis}

The analysis of variance (ANOVA) was executed to test the differences among soil properties $(\mathrm{P}<0.05)$ using statistical package SPSS version 19.0 (SPSS, Chicago, IL, USA).

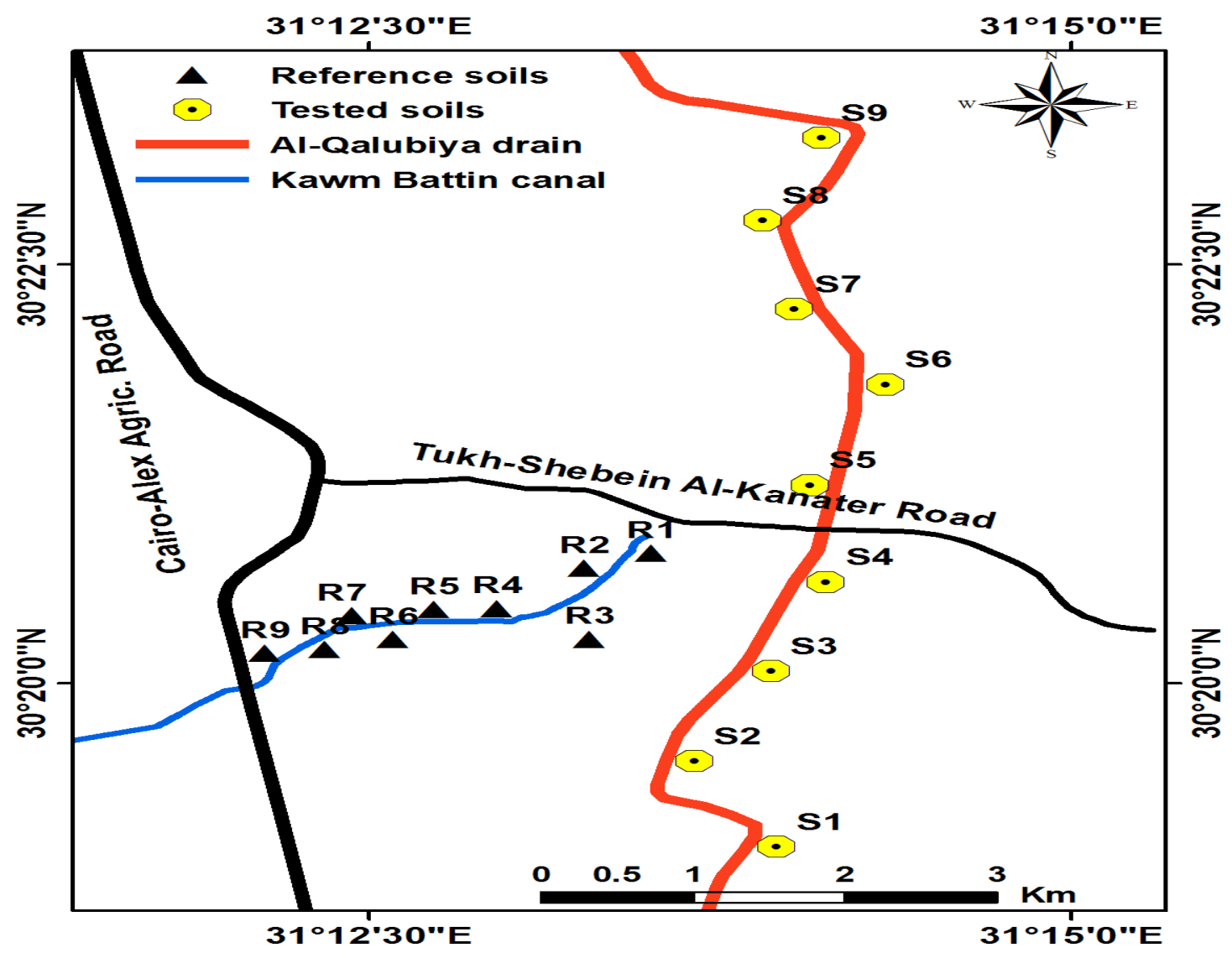

Fig. 2. Locations of soil samples 


\section{Results and Discussions}

\section{Water quality for irrigation}

Results in Table 1 indicate that the Nile fresh water showed safe limits for irrigation since all the studied parameters were below the permissible levels. The means of the parameters for the wastewater were significantly $(\mathrm{P}<0.05)$ higher than those of the Nile fresh water, except the Mgratio, as an insignificant difference was observed between the two sources. The wastewater had a $\mathrm{pH}$ increase of 0.29 units compared to the Nile fresh water; however, it remained within the normal range (6.5-8.4) for irrigation set by FAO (1994). The higher $\mathrm{pH}$ is attributed to the higher content of $\mathrm{HCO}_{3}$ ions in the wastewater compared to the fresh water (Maskooni et al., 2017).The EC and total dissolved solids (TDS) were 3.18 and 3.15 folds, respectively higher than those of the Nile fresh water due to the continuous discharge of brackish effluents along the drain. According to FAO (1994), the wastewater warranted slight to moderate salinity hazards(EC,0.7-3.0 $\mathrm{dSm}^{-1}$; TDS, 450-2000 $\mathrm{mg} \mathrm{L}^{-1}$ ). Although the sodium adsorption ratio (SAR) of the wastewater was higher than the Nile fresh water by 10.42 folds, nopotential infiltration hazard was observed since values of EC and SAR that determine the hazards (FAO, 1994) remained within the safe limit. According to FAO (1992), the Nile fresh water had low suspended solids $\left(<100 \mathrm{mg} \mathrm{L}^{-1}\right)$, while the wastewater had medium solids (200-350 mg $\left.\mathrm{L}^{-1}\right)$. Also, an entire absence of the $\mathrm{BOD}_{5}$ was in the Nile fresh water, while medium value (100-200 $\mathrm{mg} \mathrm{L}^{-1}$ ) was in the wastewater. Slight to moderate toxicity hazards related to $\mathrm{Na}$ (SAR 3-9) and $\mathrm{Cl}(4-$ $10 \mathrm{mmolc} \mathrm{L}^{-1}$ ) for surface irrigation (FAO, 1994). The contents of $\mathrm{NH}_{4}, \mathrm{NO}_{3}, \mathrm{PO}_{4}, \mathrm{SO}_{4}$, and $\mathrm{K}$ were $2.68,4.90,7.33,8.21$, and 2.49 folds, respectively higher than those of the Nile fresh water. Such values indicated higher contents of $\mathrm{NH}_{4}, \mathrm{NO}_{3}$, $\mathrm{PO}_{4}$, and $\mathrm{K}$ than the permissible limits (FAO, 1994). However, $\mathrm{PO}_{4}$ according to the Egyptian code for the long-term reuse of treated wastewater in agriculture (ECP-501, 2015) remained within the safe limits, as its content did not exceed 30 $\mathrm{mg} \mathrm{L}^{-1}$.Usually, wastewater contains reasonable amounts of plant nutrients than the fresh water, and thus it provides an alternative source for saving inorganic fertilizers (Ghosh et al., 2012).

EC, electrical conductivity; TDS, total dissolved solids; TSS, total suspended solids; BOD, biological oxygen demand; SAR, sodium adsorption ratio; $\mathrm{RSC}$, residual sodium carbonate;
$\mathrm{TH}$, total hardness; values of water quality are means \pm standards error; a, b means followed by different superscripts in the row represent significant different $(\mathrm{P}<0.05)$; recommended limit according to $*$ Egyptian code for reuse of the treated wastewater in agriculture for long-term; ${ }^{1}$ FAO (1994), ${ }^{2}$ FAO (1992), ${ }^{3}$ USDA (1954), ${ }^{4}$ Twort et al. (2000) and ${ }^{5}$ FAO/UNESCO (1973).

Slight amounts of $\mathrm{Cu}, \mathrm{Ni}$ and $\mathrm{Pb}$ were detected in the Nile fresh water, while $\mathrm{Cd}, \mathrm{Cr}, \mathrm{Co}, \mathrm{Fe}$, $\mathrm{Mn}$, and $\mathrm{Zn}$ were below the detection limit. On the other hand, metals content in the wastewater weresignificantly $(\mathrm{P}<0.05)$ higher than the Nile fresh water. For the wastewater, $\mathrm{Cd}, \mathrm{Cr}, \mathrm{Co}$, $\mathrm{Cu}, \mathrm{Fe}, \mathrm{Mn}, \mathrm{Ni}$, and $\mathrm{Zn}$ would pose a pollution problem, as their contents exceeded the safe limit for use according to FAO (1994), while $\mathrm{Pb}$ remained within the safe limit. On the other hand, $\mathrm{Zn}$ remained below the Egyptian environmental standards (ECP-501, 2015) since its content did not exceed the maximum recommended value ( $5.0 \mathrm{mg} \mathrm{L}^{-1}$ ). The continuous discharge of industrial effluents along the drain affected negatively the drain-water quality and led to the accumulation of toxic metals. The total hardness (TH) of the wastewater was 2.13 folds higher than the Nile fresh water, and the former was very hard, while the latter was moderately hard (Twort et al., 2000). The significance of $\mathrm{TH}$ in waters goes beyond the fact that it determines the toxicity of trace metals; $\mathrm{Cu}$ and $\mathrm{Zn}$, as the higher $\mathrm{TH}$, the lower the toxicity of both metals (Chapman, 1996). Concerning the hazardous effect of $\mathrm{HCO}_{3}$ ions, the Nile fresh water showed negative values of residual sodium carbonate (RSC), indicating a safe use (USDA, 1954), while the wastewater was marginally suitable (1.25-2.5 mmolc $\left.\mathrm{L}^{-1}\right)$. No $\mathrm{Mg}$ hazards related to the two sources since $\mathrm{Mg}$-ratio was less than 50\%(FAO/UNESCO, 1973).

\section{Impact of water quality on the soil physicochemical properties}

Results shown in Table 2 reveal an insignificant $(\mathrm{P}<0.05) \mathrm{pH}$ increase of 0.09 units in the wastewater-irrigated soils over the reference soils. However, the $\mathrm{pH}$ changed according to Soil Science Division Staff (2017) from slightly alkaline (7.4-7.8) in the reference soils to moderately alkaline (7.9-8.4) in the wastewaterirrigated soils. Normally, soils with high clay and organic matter content are susceptible to little $\mathrm{pH}$ changes over an extended period due to the strong buffering capacity (Wang et al., 2015). The mean 
value of EC in the wastewater-irrigated soils was significantly $(\mathrm{P}<0.05) 2.38$-folds higher than the reference soils due to the high soluble salts in the wastewater. As a result, the soils changed according to Soil Science Division Staff (2017)from nonsaline $\left(<2 \mathrm{dS} \mathrm{m}^{-1}\right)$ to very slightly saline $(2-4 \mathrm{dS}$ $\left.\mathrm{m}^{-1}\right)$.

TABLE 1 . Water quality parameters for irrigation water.

\begin{tabular}{|c|c|c|c|c|c|}
\hline \multirow{2}{*}{ Parameter } & \multirow{2}{*}{ Unit } & \multirow{2}{*}{ Nile fresh water } & \multirow{2}{*}{ Wastewater } & \multicolumn{2}{|c|}{$\begin{array}{l}\text { Recommended } \\
\text { maximumlimit }\end{array}$} \\
\hline & & & & Egypt* & World \\
\hline \multirow{6}{*}{$\begin{array}{l}\mathrm{pH} \\
\mathrm{EC} \\
\mathrm{TDS} \\
\mathrm{TSS} \\
\mathrm{BOD}_{5}\end{array}$} & & Physicochemical & & & \\
\hline & --- & $7.18 \pm 0.04^{b}$ & $7.47 \pm 0.03$ a & --- & $6.5-8.4^{1}$ \\
\hline & $\mathrm{dS} \mathrm{m}^{-1}$ & $0.39 \pm 0.01^{\mathrm{b}}$ & $1.24 \pm 0.05^{\mathrm{a}}$ & -- & $0.7-3.0^{1}$ \\
\hline & $\mathrm{mg} \mathrm{L}^{-1}$ & $246.71 \pm 7.30^{b}$ & $777.86 \pm 14.32^{\text {a }}$ & $2000^{2}$ & $450-2000^{1}$ \\
\hline & $\mathrm{mg} \mathrm{L}^{-1}$ & $49.81 \pm 0.76^{b}$ & $120.15 \pm 5.77^{\mathrm{a}}$ & --- & $350^{2}$ \\
\hline & $\mathrm{mg} \mathrm{L}^{-1}$ & $0.00 \pm 0.00^{b}$ & $135.33 \pm 2.60^{\mathrm{a}}$ & --- & $300^{2}$ \\
\hline & & Cation and anions & & & \\
\hline $\mathrm{Na}^{+}$ & $\mathrm{mg} \mathrm{L}^{-1}$ & $8.74 \pm 0.21^{b}$ & $133.40 \pm 1.26^{\mathrm{a}}$ & 230 & 920 \\
\hline $\mathrm{Ca}^{2+}$ & $\mathrm{mg} \mathrm{L}^{-1}$ & $33.4 \pm 1.76^{b}$ & $72.01 \pm 1.15^{\mathrm{a}}$ & 230 & 400 \\
\hline $\mathrm{Mg}^{2+}$ & $\mathrm{mg} \mathrm{L}^{-1}$ & $16.44 \pm 0.41^{\mathrm{b}}$ & $34.20 \pm 0.35^{\mathrm{a}}$ & 100 & 60 \\
\hline $\mathrm{Cl}^{-}$ & $\mathrm{mg} \mathrm{L}^{-1}$ & $39.05 \pm 2.05^{\mathrm{b}}$ & $152.64 \pm 4.10^{\mathrm{a}}$ & --- & $350^{1}$ \\
\hline \multirow{2}{*}{$\mathrm{HCO}_{3}^{-}$} & $\operatorname{mg~L}{ }^{-1}$ & $125.86 \pm 4.17^{b}$ & $530.09 \pm 10.61^{\mathrm{a}}$ & 400 & 610 \\
\hline & & Nutrients & & & \\
\hline $\mathrm{NH}_{4}-\mathrm{N}$ & $\mathrm{mg} \mathrm{L}^{-1}$ & $4.33 \pm 0.16^{\mathrm{b}}$ & $11.61 \pm 0.21^{\mathrm{a}}$ & --- & $5^{1}$ \\
\hline $\mathrm{NO}_{3}-\mathrm{N}$ & $\mathrm{mg} \mathrm{L}^{-1}$ & $3.87 \pm 0.09^{b}$ & $18.97 \pm 0.28^{\mathrm{a}}$ & --- & $10^{1}$ \\
\hline $\mathrm{PO}_{4}$ & $\mathrm{mg} \mathrm{L}^{-1}$ & $0.51 \pm 0.05^{b}$ & $3.74 \pm 0.06^{\mathrm{a}}$ & 30 & $2^{1}$ \\
\hline K & $\mathrm{mg} \mathrm{L}^{-1}$ & $1.41 \pm 0.26^{\mathrm{b}}$ & $11.57 \pm 0.34^{\mathrm{a}}$ & --- & $2^{1}$ \\
\hline \multirow[t]{2}{*}{$\mathrm{SO}_{4}$} & $\mathrm{mg} \mathrm{L}^{-1}$ & $7.20 \pm 0.28^{b}$ & $17.92 \pm 0.58^{\mathrm{a}}$ & 500 & 960 \\
\hline & & Heavy metals & & & \\
\hline $\mathrm{Cd}$ & $\mathrm{mg} \mathrm{L}^{-1}$ & $<0.001$ & $0.05 \pm 0.01$ & 0.01 & $0.01^{1}$ \\
\hline $\mathrm{Cr}$ & $m g L^{-1}$ & $<0.001$ & $0.43 \pm 0.03$ & 0.10 & $0.10^{1}$ \\
\hline Co & $\mathrm{mg} \mathrm{L}^{-1}$ & $<0.001$ & $0.25 \pm 0.01$ & 0.05 & $0.05^{1}$ \\
\hline $\mathrm{Cu}$ & $\mathrm{mg} \mathrm{L}^{-1}$ & $0.03 \pm 0.01^{\mathrm{b}}$ & $2.93 \pm 0.09^{\mathrm{a}}$ & 0.20 & $0.20^{1}$ \\
\hline $\mathrm{Fe}$ & $\mathrm{mg} \mathrm{L}^{-1}$ & $<0.008$ & $6.66 \pm 0.27$ & 5.0 & $5.0^{1}$ \\
\hline Mn & $m g L^{-1}$ & $<0.005$ & $0.96 \pm 0.09$ & 0.20 & $0.20^{1}$ \\
\hline $\mathrm{Ni}$ & $\mathrm{mg} \mathrm{L}^{-1}$ & $0.04 \pm 0.01^{\mathrm{b}}$ & $0.88 \pm 0.04^{\mathrm{a}}$ & 0.20 & $0.20^{1}$ \\
\hline $\mathrm{Pb}$ & $\mathrm{mg} \mathrm{L}^{-1}$ & $0.06 \pm 0.01^{\mathrm{b}}$ & $0.82 \pm 0.18^{\mathrm{a}}$ & 5.0 & $5.0^{1}$ \\
\hline \multirow[t]{2}{*}{$\mathrm{Zn}$} & $\mathrm{mg} \mathrm{L}^{-1}$ & $<0.001$ & $3.50 \pm 0.03$ & 5.0 & $2.0^{1}$ \\
\hline & & Miscellaneous & & & \\
\hline SAR & --- & $0.31 \pm 0.01^{\mathrm{b}}$ & $3.23 \pm 0.01^{\mathrm{a}}$ & $6-9$ & 9 \\
\hline RSC & mmolc $\mathrm{L}^{-1}$ & $-0.97 \pm 0.19^{b}$ & $2.24 \pm 0.16^{\mathrm{a}}$ & --- & $2.5^{3}$ \\
\hline $\mathrm{TH}$ & $\mathrm{mg} \mathrm{L}^{-1}$ & $151.67 \pm 6.01^{b}$ & $322.50 \pm 4.33^{\mathrm{a}}$ & --- & $300^{4}$ \\
\hline Mg-ratio & --- & $45.11 \pm 0.77^{\mathrm{a}}$ & $44.19 \pm 0.15^{\text {a }}$ & --- & $50^{5}$ \\
\hline
\end{tabular}

EC, electrical conductivity; TDS, total dissolved solids; TSS, total suspended solids; BOD, biological oxygen demand; SAR, sodium adsorption ratio; RSC, residual sodium carbonate; $\mathrm{TH}$, total hardness; values of water quality are means \pm standards error; $\mathrm{a}$, $\mathrm{b}$ means followed by different superscripts in the row represent significant different $(\mathrm{P}<0.05)$; recommended limit according to * Egyptian code for reuse of the treated wastewater in agriculture for long-term; 1 FAO (1994), 2 FAO (1992), 3 USDA (1954), 4Twort et al. (2000) and (5 FAO/UNESCO (19973 
TABLE 2. Physicochemical properties of the studied soils

\begin{tabular}{|c|c|c|c|c|c|c|}
\hline \multirow[t]{2}{*}{ Properties } & \multicolumn{3}{|c|}{ Fresh water-irrigated soils } & \multicolumn{3}{|c|}{ Wastewater-irrigated soils } \\
\hline & Min & Max & Mean \pm SE & Min & Max & Mean \pm SE \\
\hline $\mathrm{pH}\left(1: 2.5 \mathrm{H}_{2} \mathrm{O}\right)$ & 7.41 & 7.80 & $7.58 \pm 0.07^{\mathrm{a}}$ & 7.45 & 7.99 & $7.67 \pm 0.04^{\mathrm{a}}$ \\
\hline $\mathrm{EC}, \mathrm{dS} \mathrm{m}^{-1}$ (Soil paste) & 0.64 & 1.75 & $0.87 \pm 0.12^{b}$ & 0.92 & 5.77 & $2.07 \pm 0.55^{\mathrm{a}}$ \\
\hline ESP & 0.35 & 0.46 & $0.48 \pm 0.04^{\mathrm{a}}$ & 0.43 & 2.15 & $0.84 \pm 0.18^{\mathrm{a}}$ \\
\hline $\mathrm{OM}, \mathrm{g} \mathrm{kg}^{-1}$ & 17.59 & 29.32 & $24.76 \pm 1.16^{\mathrm{a}}$ & 24.23 & 35.88 & $28.09 \pm 1.24^{\mathrm{a}}$ \\
\hline Sand, \% & 24.82 & 37.13 & $29.58 \pm 1.55^{\mathrm{a}}$ & 23.27 & 35.68 & $28.06 \pm 1.36^{\mathrm{a}}$ \\
\hline Silt, \% & 12.27 & 25.16 & $19.65 \pm 1.80^{\mathrm{a}}$ & 13.89 & 27.07 & $21.09 \pm 1.83^{\mathrm{a}}$ \\
\hline Clay, \% & 44.82 & 57.28 & $50.99 \pm 1.25^{\mathrm{a}}$ & 47.78 & 58.39 & $51.08 \pm 1.16^{\mathrm{a}}$ \\
\hline Texture & \multicolumn{3}{|c|}{ Clay } & \multicolumn{3}{|c|}{ Clay } \\
\hline WHC, \% & 33.70 & 36.76 & $35.44 \pm 0.25^{\mathrm{a}}$ & 34.33 & 38.11 & $36.19 \pm 0.43^{\mathrm{a}}$ \\
\hline $\mathrm{BD}, \mathrm{Mg} \mathrm{m}^{-3}$ & 1.18 & 1.34 & $1.25 \pm 0.02^{\mathrm{a}}$ & 1.11 & 1.28 & $1.21 \pm 0.02^{\mathrm{a}}$ \\
\hline Total $\mathrm{N}, \mathrm{g} \mathrm{kg}^{-1}$ & 2.81 & 4.21 & $3.39 \pm 0.24^{b}$ & 4.21 & 6.80 & $4.98 \pm 0.28^{\mathrm{a}}$ \\
\hline Available $\mathrm{P}, \mathrm{mg} \mathrm{kg}^{-1}$ & 1.42 & 9.94 & $3.77 \pm 0.87^{\mathrm{b}}$ & 3.25 & 13.19 & $8.24 \pm 1.13^{\mathrm{a}}$ \\
\hline Available $\mathrm{K}, \mathrm{mg} \mathrm{kg}^{-1}$ & 197.43 & 679.83 & $452.78 \pm 53.01^{\mathrm{a}}$ & 298.01 & 862.92 & $549.32 \pm 56.63^{\mathrm{a}}$ \\
\hline Available Fe, $\mathrm{mg} \mathrm{kg}^{-1}$ & 8.22 & 11.90 & $9.99 \pm 2.10^{\mathrm{b}}$ & 14.80 & 30.40 & $20.62 \pm 0.48^{\mathrm{a}}$ \\
\hline Available $\mathrm{Mn}, \mathrm{mg} \mathrm{kg}^{-1}$ & 2.14 & 4.10 & $2.90 \pm 0.23^{b}$ & 5.16 & 8.20 & $6.33 \pm 0.43^{\mathrm{a}}$ \\
\hline
\end{tabular}

Similarly, there was an insignificant difference $(\mathrm{P}<0.05)$ in soil organic matter $(\mathrm{OM})$ between the soils that had an adequate $\left(>12.9 \mathrm{~g} \mathrm{~kg}^{-1}\right) \mathrm{OM}$ content (Estefan et al., 2013). Consequently, the effect of wastewater irrigation on soil physical properties; bulk density (BD) and water holding capacity (WHC) has been masked, as insignificant differences $(\mathrm{P}<0.05)$ in the two parameters were observed between the soils. Bassouny and Abuzaid (2017) indicated that the changes in soil $\mathrm{BD}$ are directly related to changing OM content, while Masto et al. (2009) attributed the variation of WHC in soils to the organic matter or clay content in soils or their combinations. Regarding plant nutrients, the wastewater irrigation caused significant increases $(\mathrm{P}<0.05)$ in total $\mathrm{N}$ by 1.47 folds and the AB-DTPA extractable P by 2.19 folds, Fe by 2.06 , and $\mathrm{Mn}$ by 2.18 folds over the reference soils due to the high nutrient load in the wastewater.On the other hand, wastewater irrigation did not significantly $(\mathrm{P}<0.05)$ affect the available $\mathrm{K}$ due to the similar clay content in the soils. Rezapour et al. (2010) indicated that type and abundance of clay minerals have a significant

Egypt. J. Soil Sci. 58, No. 1 ( 2018 ) role on $\mathrm{K}$ availability, especially under arid and semi-arid conditions.

\section{Heavy metals content in soils}

Results in Table 3 indicate that the wastewater irrigation resulted in a significant build-up $(\mathrm{P}<$ 0.05 ) in heavy metals content compared to the reference soils. The mean values of $\mathrm{Cd}, \mathrm{Cr}, \mathrm{Co}$, $\mathrm{Cu}, \mathrm{Ni}, \mathrm{Pb}$ and $\mathrm{Zn}$ 6.29, 8.62, 49.0, 5.56, 14.24, 13.88 , and 3.03 folds, respectively higher than those of the reference soils. The accumulation of heavy metals in the wastewater irrigated soils could be arranged as follows: $\mathrm{Zn}>\mathrm{Cr}>\mathrm{Cu}>\mathrm{Ni}$ $>\mathrm{Pb}>\mathrm{Co}>\mathrm{Cd}$. Studies demonstrated higher heavy metals accumulation in soils of the Nile Delta region which have been irrigated with the wastewater for long periods than those irrigated with the Nile fresh water (Galal, 2015 and Mahmoud \& Ghoneim, 2016)

\section{Heavy metals contamination/pollution in soil}

Soil contamination points to metal content in soil linked to clay and organic matter content and might not have immediate negative impacts on plant growth or the environment, while soil 
pollution indicates further limits induce negative environmental risks (Lacatusu, 1998). The mean values of heavy metals in the reference soils did not exceed A value (Table 4), indicating a safe use for agricultural production. Very slight contamination degree was related to $\mathrm{Co}$, $\mathrm{Cr}, \mathrm{Ni}$, and $\mathrm{Pb}$, slight to $\mathrm{Cd}$, while $\mathrm{Cu}$ and $\mathrm{Zn}$ posed moderate contamination (Table 5). In the wastewater-irrigated soils, the mean values of $\mathrm{Cd}, \mathrm{Cr}, \mathrm{Pb}$, and $\mathrm{Zn}$ were below A values, while $\mathrm{Co}, \mathrm{Cu}$, and $\mathrm{Ni}$ surpassed $\mathrm{A}$ values. Severe contamination degrees were associated with $\mathrm{Cd}$, $\mathrm{Cr}$, and $\mathrm{Pb}$ and very severe for $\mathrm{Zn}$, while $\mathrm{Co}, \mathrm{Cu}$ and $\mathrm{Ni}$ warranted slight pollution, as the $\mathrm{C} / \mathrm{P}$ was greater than 1.0.However, $\mathrm{Co}, \mathrm{Cu}$, and $\mathrm{Ni}$ in soils were higher than level A, they did not exceed level $B$ value (the maximum acceptable limit), which means that the soils could be used for agricultural production under certain precautions. Once the contaminant surpassed level $\mathrm{B}$, land use is mainly directed towards the commercial or industrial use, while exceeding level $\mathrm{C}$ indicates that the land is not proper for any agricultural, commercial or industrial use (Abdel-Rahman, 2014). Concerning the overall pollution, a multiple pollution index (MPI) of 0.85 for the reference soils indicates that the soils remained within the safe domain $(<1.0)$, while the corresponding value for the wastewaterirrigated soils was 6.74 , indicating a pollution problem (Nunes et al., 2003).

To avoid the potential environmental risks and to achieve sustainable agricultural production in the studied area, preventive measures are required. The first step is to upgrade water quality and alleviate toxic metals load by 1 ). controlling the unofficial discharge of industrial as well as domestic effluent along the drain (Elbana et al., 2017); 2). mixing the wastewater with the fresh water before the reuse (Myszograj et al., 2014); 3). application of constructed wetland system (Stottmeister et al., 2006) at small scale; 4). using biological filtration through water plants (Purakayastha and Chhonkar, 2009); and 5). implementing effective media filter through irrigation (Haynes, 2015). The second step is to apply an appropriate on-farm treatment for the insitu soil remediation to clean-up the contaminants by means of phytoremediation and to minimizing metal uptake and accumulation in foods and forage crops using physical, chemical and biological techniques (Surriya et al., 2015).

\section{Conclusion}

Low-quality water with high levels of heavy metals had adverse effects on soil qualities. Longterm wastewater irrigation resulted in a significant $(\mathrm{P}<0.05)$ build-up in salinity, total $\mathrm{N}$, available $\mathrm{P}$, $\mathrm{Fe}$ and $\mathrm{Mn}$ and total heavy metals compared with the reference soils, while insignificant differences were observed concerning $\mathrm{pH}, \mathrm{ESP}$, organic matter, claycontent, water holding capacity, bulk density and available $\mathrm{K}$. Heavy metals accumulation in soils followed the decreasing order of $\mathrm{Zn}>\mathrm{Cr}>$ $\mathrm{Cu}>\mathrm{Ni}>\mathrm{Pb}>\mathrm{Co}>\mathrm{Cd}$. The Dutch model and multiple pollution index (MPI) indicated a safe use for reference soils, but a pollution problem for the wastewater-irrigated soils.

TABLE 3. Total heavy metals content, $\mathrm{mg} \mathrm{kg}^{-1}$ in the studied soils

\begin{tabular}{lcccccc}
\hline \multirow{2}{*}{$\begin{array}{l}\text { Heavy metals, } \\
\mathrm{mg} \mathrm{kg}^{-1}\end{array}$} & \multicolumn{3}{c}{ Fresh water-irrigated soils } & \multicolumn{3}{c}{ Wastewater-irrigated soils } \\
& Min & Max & Mean \pm SE & Min & Max & Mean \pm SE \\
\hline $\mathrm{Cd}$ & 0.01 & 0.20 & $0.08 \pm 0.03^{\mathrm{b}}$ & 0.32 & 1.04 & $0.50 \pm 0.07^{\mathrm{a}}$ \\
$\mathrm{Cr}$ & 6.35 & 13.40 & $9.12 \pm 0.73^{\mathrm{b}}$ & 36.92 & 125.96 & $78.65 \pm 9.08^{\mathrm{a}}$ \\
$\mathrm{Co}$ & 0.02 & 1.21 & $0.69 \pm 0.16^{\mathrm{b}}$ & 25.11 & 48.46 & $33.76 \pm 2.38^{\mathrm{a}}$ \\
$\mathrm{Cu}$ & 10.26 & 15.69 & $12.95 \pm 0.66^{\mathrm{b}}$ & 55.96 & 101.73 & $73.18 \pm 5.04^{\mathrm{a}}$ \\
$\mathrm{Ni}$ & 2.18 & 7.88 & $4.43 \pm 0.61^{\mathrm{b}}$ & 32.50 & 90.58 & $63.08 \pm 6.13^{\mathrm{a}}$ \\
$\mathrm{Pb}$ & 2.58 & 5.38 & $4.05 \pm 0.38^{\mathrm{b}}$ & 23.27 & 112.88 & $56.26 \pm 11.88^{\mathrm{a}}$ \\
$\mathrm{Zn}$ & 45.96 & 66.35 & $56.31 \pm 2.61^{\mathrm{b}}$ & 143.85 & 213.46 & $170.49 \pm 7.76^{\mathrm{a}}$ \\
\hline
\end{tabular}

$\overline{\mathrm{SE}}$, standard error; ${ }^{\mathrm{a}, \mathrm{b}}$ means followed by different superscripts in row represent significant different $(\mathrm{P}<$ $0.05)$. 
TABLE 4. The Dutch model used for evaluating heavy metals contamination/pollution

\begin{tabular}{|c|c|c|c|c|c|c|c|}
\hline \multirow{3}{*}{ Metals } & \multirow{3}{*}{$\begin{array}{l}\text { A values, } \\
\text { mg kg-1 }^{-1}\end{array}$} & \multirow{3}{*}{$\begin{array}{l}\text { B values, } \\
\text { mg kg-1 }^{-1}\end{array}$} & \multirow{3}{*}{$\begin{array}{c}\text { C values, } \\
\text { mg kg-1 }^{-1}\end{array}$} & \multicolumn{4}{|c|}{ The current study, mg kg-1 } \\
\hline & & & & \multicolumn{2}{|c|}{ Reference soils } & \multicolumn{2}{|c|}{$\begin{array}{l}\text { Wastewater- } \\
\text { irrigated soils }\end{array}$} \\
\hline & & & & $\mathbf{A}$ & Mean & $\mathbf{A}$ & Mean \\
\hline $\mathrm{Cd}$ & $0.4+0.007($ Clay $+3 \mathrm{OM})$ & 5 & 20 & 0.81 & 0.08 & 0.82 & 0.50 \\
\hline Co & 20 & 50 & 300 & 20 & 0.69 & 20 & 33.76 \\
\hline $\mathrm{Cr}$ & $50+2$ Caly & 250 & 800 & 151.79 & 9.12 & 152.84 & 78.65 \\
\hline $\mathrm{Cu}$ & $15+0.6($ Clay + OM $)$ & 100 & 500 & 47.08 & 12.95 & 47.54 & 73.18 \\
\hline $\mathrm{Ni}$ & $10+$ Clay & 100 & 500 & 60.99 & 4.43 & 61.42 & 63.08 \\
\hline $\mathrm{Pb}$ & $50+$ Clay + OM & 150 & 600 & 103.46 & 4.05 & 104.23 & 56.26 \\
\hline $\mathrm{Zn}$ & $50+1.5(2 \mathrm{Clay}+\mathrm{OM})$ & 500 & 3000 & 206.76 & 56.31 & 208.47 & 170.49 \\
\hline
\end{tabular}

A, normal level in good soils; B, maximum acceptable limit of the contamination for the agricultural purposes; C, needs immediate soil clean-up measures.

TABLE 5. Levels of soil contamination/pollution of the investigated soils

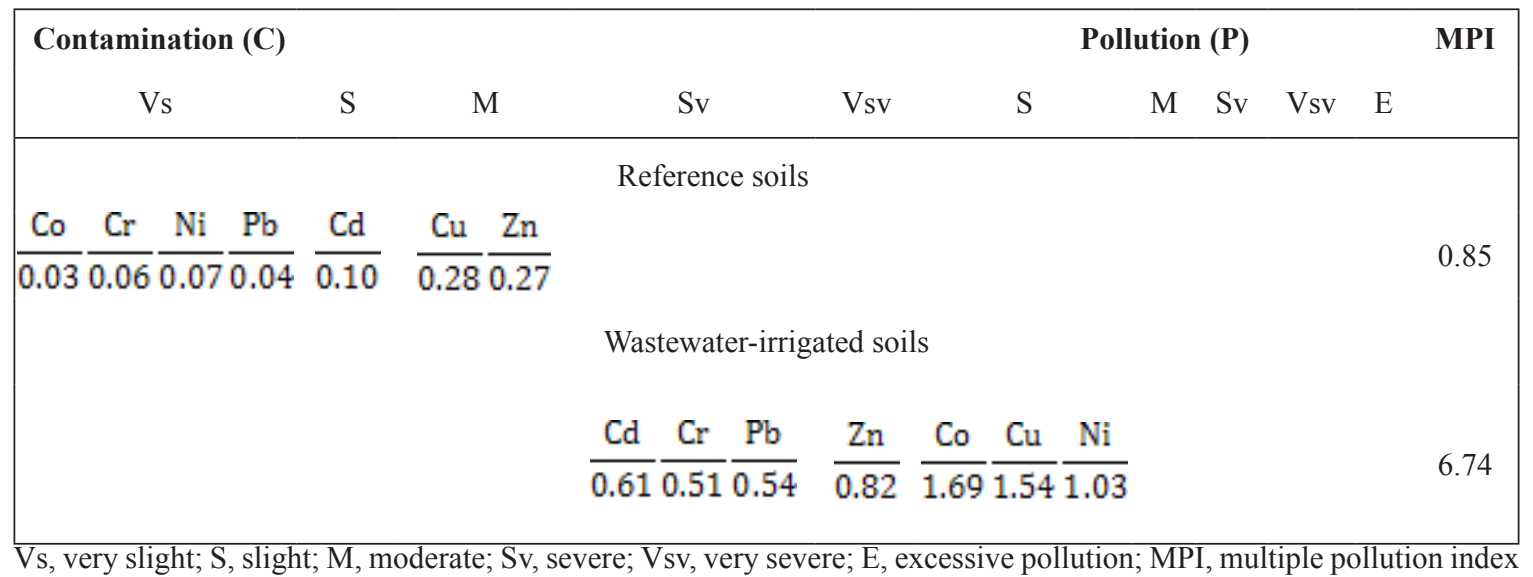

\section{References}

Abdel-Rahman, S.A. (2014) Studies on pollution of some irrigation water sources and its effect on soil and growing plants. MSc Thesis. Faculty of Agriculture, Benha University, Egypt

Abdel Meguid, M. (2017) Key features of the Egypt's water and agricultural resources. In: Negm, A.M. (Ed.), Conventional Water Resources and Agriculture in Egypt. Springer Berlin Heidelberg, Berlin, Heidelberg, pp. 1-61.

Ali, H.M., Siddiqui, M.H., Khamis, M.H., Hassan, F.A., Salem, M.Z.M. and El-Mahrouk, E.-S.M. (2013) Performance of forest tree Khaya senegalensis (Desr.) A. Juss. under sewage effluent irrigation. Ecol. Eng. 61, 117-126.

APHA (2005) Standard methods for the examination of water and wastewater. APHA-AWWA-WEF, Washington, DC.

Egypt. J. Soil Sci. 58, No. 1 ( 2018 )
Bassouny, M.A., Abuzaid, A.S. (2017) Impact of biogas slurry on some physical properties in sandy and calcareous soils, Egypt. Int. J. Plant Soil Sci. 16, 1-11.

Chapman, D.V. (1996) Water quality assessments: a guide to the use of biota, sediments and water in environmental monitoring.UNESCO/WHO/UNEP, London UK.

ECP-501 (2015) Egyptian code of practice for the use of treated municipal wastewater for agricultural purposes. The Ministry of Housing Utilities and Urban Communities. (In Arabic).

Elbana, T.A., Bakr, N., George, B. and Elbana, M. (2017) Assessment of marginal quality water for sustainable irrigation management: Case study of Bahr El-Baqar area, Egypt. Water, Air, \& Soil Pollution, 228, 214. 
Estefan, G., Sommer, R. and Ryan, J. (2013) Methods of soil, plant, and water analysis: A manual for the West Asia and North Africa region. ICARDA (International Center for Agricultural Research in the Dry Areas), Beirut, Lebanon.

FAO (1992) Wastewater treatment and use in agriculture. FAO irrigation and drainage paper 47 . Food and Agriculture Organization of the United Nations, Rome, Italy.

FAO (1994) Water quality for agriculture: FAO Irrigation and Drainage Paper 29. Revision. 1. pp. 1-130.

FAO/UNESCO (1973) Irrigation, drainage and salinity. An international sourcebook. FAO/UNESCO/ Hutchinson \& CO, London, UK.

Galal, H.A. (2015) Long-term effect of mixed wastewater irrigation on soil properties, fruit quality and heavy metal contamination of citrus. Am. J. Environ. Prot. 3, 100-105.

Ghosh, A.K., Bhatt, M.A., Agrawal, H.P. (2012) Effect of long-term application of treated sewage water on heavy metal accumulation in vegetables grown in Northern India. Environ. Monit. Assess.184, 10251036.

Haynes, R.J. (2015) Use of Industrial wastes as media in constructed wetlands and filter beds-prospects for removal of phosphate and metals from wastewater streams. Crit. Rev. Environ. Sci. Technol. 45, 10411103.

International Center For Agricultural Research in the Dry Areas (ICARDA) (2011) Water and agriculture in Egypt. Technical paper based on the EgyptAustralia-ICARDA Workshop on On-farm Wateruse Efficiency. June 2011, Cairo-Egypt

Jalali, M. and Merrikhpour, H. (2008) Effects of poor quality irrigation waters on the nutrient leaching and groundwater quality from sandy soil. Environ. Geol. 53, 1289-1298.

Klute, A. (1986) Methods of Soil Analysis: Part 1-Physical and mineralogical methods. Soil Science Society of America, American Society of Agronomy, Madison, WI.

Lacatusu, R. (1998) Appraising levels of soil contamination and pollution with heavy metals. European Soil Bureau Research report No. 4, 393404.

Loutfy, N.M. (2011) Reuse of wastewater in Mediterranean region, Egyptian Experience. In: Barceló, D., Petrovic, M. (Ed.), Waste water Treatment and Reuse in the Mediterranean Region.
Springer Berlin Heidelberg, Berlin, Heidelberg, pp. 183-213.

Mahmoud, E.K. and Ghoneim, A.M. (2016) Effect of polluted water on soil and plant contamination by heavy metals in El-Mahla El-Kobra, Egypt. Solid Earth, 7, 703-711.

Mahmoud, M.A. and El-Bably, A.Z. (2017) Crop water requirements and irrigation efficiencies in Egypt. In: Negm, A.M. (Ed.), Conventional Water Resources and Agriculture in Egypt. Springer Berlin Heidelberg, Berlin, Heidelberg, pp. 1-17.

Marzaioli, R., D'Ascoli, R., Pascale, R.A.D., Rutigliano, F.A. (2010) Soil quality in a Mediterranean area of Southern Italy as related to different land use types. Appl. Soil Ecol.44, 205-212.

Maskooni, E.K., Kompanizare, M. and Afzali, S.F. (2017) Chemical assessment of dam water irrigation effects on groundwater qualities in Bigherd plain, Fars Province, Iran. Environ. Earth Sci.76, 238.

Masto, R.E., Chhonkar, P.K., Singh, D. and Patra, A.K. (2009) Changes in soil quality indicators under long-term sewage irrigation in a sub-tropical environment. Environ. Geol.56, 1237-1243.

Myszograj, S., Qteishat, O., Sadecica, Z., Jedrczak, A. and Suchowska-Kisielewicz, M. (2014) Possibilities of reuse of treated wastewater for irrigation purposes in the northern Jordan valley. Environ. Prot. Eng. 40, 17-31.

Nunes, M., Da Silva, E.F. and De Almeida, S. (2003) Assessment of water quality in the Caima and Mau river basins (Portugal) using geochemical and biological indices. Water, Air, and Soil Pollution 149, 227-250.

Peña-Icart, M., Tagle, M.E.V., Alonso-Hernández, C., Hernández, J.R., Behar, M. and Alfonso, M.S.P. (2011) Comparative study of digestion methods EPA 3050B ( $\mathrm{HNO} 3-\mathrm{H} 2 \mathrm{O} 2-\mathrm{HCl})$ and ISO 11466.3 (aqua regia) for $\mathrm{Cu}, \mathrm{Ni}$ and $\mathrm{Pb}$ contamination assessment in marine sediments. Mar. Environ. Res.72, 60-66.

Purakayastha, T.J. and Chhonkar, P.K. (2009) Phytoremediation of heavy metal contaminated Soils. In: Sherameti, I., Varma, A. (Ed.), Soil Heavy Metals, Soil Oiology, Vol 19. Springer-Verlag, Berlin Heidelberg, p. 496.

Rashed, M., Awad, S.R., Salam, M.A. and Smidt, E. (1995) Monitoring of groundwater in Gabal ElAsfar wastewater irrigated area (greater Cairo). Water Sci. Technol. 32, 163-169. 
Rezapour, S. and Samadi, A. (2011) Soil quality response to long-term wastewater irrigation in Inceptisols from a semi-arid environment. Nutr. Cycl. Agroecosyst. 91, 269-280.

Rezapour, S., Samadi, A., Jafarzadeh, A. and Oustan, S. (2010) Impact of clay mineralogy and landscape on potassium forms in calcareous soils, Urmia region. J. Agric. Sci. Tec.12, 495-507.

Soil Science Division Staff (2017) Soil survey manual. USDA Handbook 18. Government Printing Office, Washington, DC.

Soil Survey Staff (2014) Keys to soil taxonomy. Department of Agriculture, Natural Resources Conservation Service, Washington, DC.

Soliman, I. (2015) Diagnosis and challenges of sustainable agricultural development in Egypt. In: Petit, M., Montaigne, E., El Hadad-Gauthier, F., García Álvarez-Coque, J.M., Mattas, K., Mili, S. (Ed.), Sustainable Agricultural Development: Challenges and Approaches in Southern and Eastern Mediterranean Countries. Springer International Publishing, Cham, pp. 19-64.

Soltanpour, P.N. and Schwab, A.P. (1977) A new soil test for simultaneous extraction of macro - and micro - nutrients in alkaline soils. Commun. Soil Sci. Plant Anal. 8, 195-207.

Sparks, D.L., Page, A.L., Helmke, P.A. and Loeppert, R.H. (1996) Methods of Soil Analysis: Part 3- Chemical Methods. Soil Science Society of America, American Society of Agronomy, Madison, WI.

Stottmeister, U., Buddhawong, S., Kuschk, P., Wiessner, A. and Mattusch, J. (2006) Constructed wetlands and their performance for treatment of water contaminated with arsenic and heavy metals. In: Twardowska, I., Allen, H.E., Häggblom, M.M. (Ed.), Soil and Water Pollution Monitoring, Protection and Remediation. Springer, Dordrecht, Netherlands, p. 637.
Surriya, O., Saleem, S.S., Waqar, K. and Kazi, A.G. (2015) Phytoremediation of soils: Prospects and challenges. In: Hakeem, K.R., Sabir, M., Öztürk, M., Mermut, A.R. (Ed.), Soil Remediation and Plants. Elsevier Inc., USA, p. 771.

Twort, A.C., Ratnayaka, D.D. and Brandt, M.J. (2000) Water Supply, Elsevier Ltd, Oxford, UK.

USDA (1954) Diagnosis and improvement of saline and alkali soils. U.S. Agric. Handbook, No. 60. U.S. Dept. Agric., , Washington D.C.

Wang, X., Tang, C., Mahony, S., Baldock, J.A. and Butterly, C.R. (2015) Factors affecting the measurement of soil $\mathrm{pH}$ buffer capacity: approaches to optimize the methods. Eur. J. Soil Sci. 66, 53-64.

Wienhold, B.J., Andrews, S.S. and Karlen, D.L. (2004) Soil quality: a review of the science and experiences in the USA. Environ. Geochem. Health, 26, 59-95.

Yadav, R.K., Minhas, P.S., Lal, K., Chaturvedi, R.K., Yadav, G. and Verma, T.P. (2015) Accumulation of metals in soils, groundwater and edible parts of crops grown under long-term irrigation with sewage mixed industrial effluents. Bull. Environ. Contam. Toxicol. 95, 200-206.

Yao, R., Yang, J., Gao, P., Zhang, J. and Jin, W. (2013) Determining minimum data set for soil quality assessment of typical salt-affected farmland in the coastal reclamation area. Soil Tillage Res. 128, 137-148.

Zidan, M.S. and Dawoud, M.A.(2013) Agriculture use of marginal water in Egypt: Opportunities and challenges. In: Shahid, S.A., Abdelfattah, M.A., Taha, F.K. (Ed.), Developments in soil salinity assessment and reclamation: Innovative thinking and use of marginal soil and water resources in irrigated agriculture. Springer Netherlands, Dordrecht, pp. 661-679.

(Received: 4/7 /2017; accepted: 30/8/2017) 
مؤشرات جودة التربة بمحافظة القليوبية المتأثرة بالري طويل الأمد بمياه الصرف الصحي

أحمد سعيد أبوزيد قسم الأراضي والمياه ـ كلية الزر اعة - جامعة بنها ـ مصر

\footnotetext{
تهذف هذه الدراسة إلى تتبع التغير ات في الخواص الكيميائية و الفيزيائية الححددة لجودة الأر اضي الرسوبية

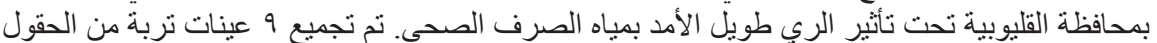

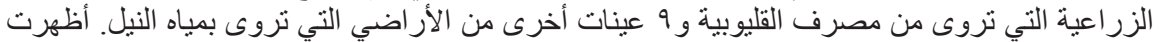

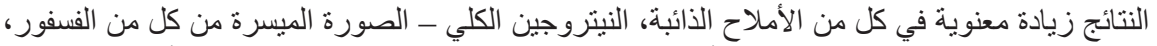

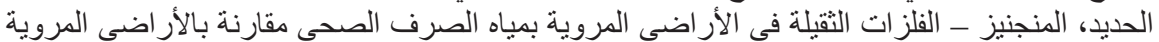

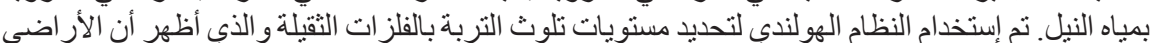

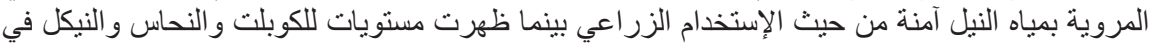

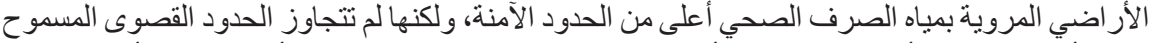

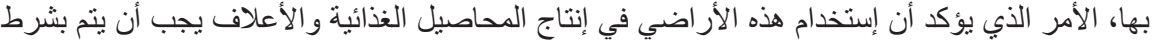

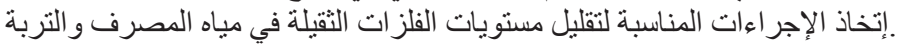

